\title{
Contraction of Wildlife Dispersal Area in Olgulului - Ololorashi Group Ranch Around Amboseli National Park, Kenya
}

\author{
Moses Makonjio Okello* and John Masila Kioko
}

SFS Center for Wildlife Management Studies, P.O. Box 27743 - 00506, Nairobi, Kenya

\begin{abstract}
A majority of large mammals from Amboseli National Park rely on group ranch wildlife dispersal areas for wet season dispersal. However, the contraction of wildlife dispersal areas around Amboseli may be increasing, but the extent is unknown. This study investigated the contraction of wildlife dispersal area by human infrastructure in Olgulului Ololorashi Group Ranch, which surrounds over 90\% of Amboseli Park. Global Positioning System (GPS) was used for location and Geographical Information System (GIS) was used for spatial analysis to determine the area occupied by the structures. The minimum distance of wildlife kept away from institutions was $275 \pm 20 \mathrm{~m}$, followed by bomas $(214 \pm 16$ $\mathrm{m})$, roads $(163 \pm 9 \mathrm{~m})$, and livestock $(192 \pm 12 \mathrm{~m})$. The minimum distance of wildlife from human infrastructure was used as an index of wildlife displacement. All infrastructure occupied an actual area of $66 \mathrm{~km}^{2}(5 \%)$ of the group ranch. This increased to $281 \mathrm{~km}^{2}(23 \%)$ with wildlife displacement. Of the area occupied by human infrastructure, fourteen settlement clusters $\left(199 \mathrm{~km}^{2}, 10.82 \%\right)$ were located. Bomas covered $10 \%$ of the group ranch area, followed by institutions $(6 \%)$, roads $(5 \%)$, and agriculture $(2.13 \%)$. The infrastructures were widely distributed in the group ranch and around the Amboseli. Although more dispersal space was available, the spatial distribution of clusters and infrastructure threaten wildlife dispersal. If the obstruction of dispersal routes is not addressed, the group ranch will be compromised as a wildlife dispersal area for Amboseli National Park.
\end{abstract}

Keywords: Amboseli National Park, Kenya, Olgulului-Ololorashi Group Ranch, wildlife conservation, wildlife dispersal areas.

\section{INTRODUCTION}

The presence of dispersal areas and migration corridors around protected areas is critical to successful wildlife conservation. Many protected areas are too small to independently support viable wildlife populations and therefore rely on surrounding areas to provide forage and water resources, breeding grounds, and mating opportunities $[1,2]$. Within the Amboseli ecosystem in southern Kenya, over $80 \%$ of large mammals from Amboseli National Park enter the neighboring Maasai group ranches during the wet season [3, 4]. However, the park is increasingly insularized by human infrastructure, but the spatial and actual extend of this insularization in recent years has not been clearly known or documented.

Insularization of Amboseli National Park has serious implications for wildlife conservation in the area, and in Kenya generally, as Amboseli is likely to become unviable ecological island $[5,6]$. As the human population in the area grows, there is an increase in the construction of houses, roads, markets, and towns, and an increased conversion of land to agricultural practices [6]. These development activities and structures around the park's and in the entire ecosystem are fragmenting wildlife habitats and blocking the movement of wildlife to national parks, and within the dispersal areas in the group ranches. Furthermore, an

*Address correspondence to this author at the SFS Center for Wildlife Management Studies, P.O. Box 27743 - 00506, Nairobi, Kenya;

Tel: +254-722-598884:

E-mail: mokello@fieldstudies.org, moses_okello@yahoo.com

"Now with the Amboseli Elephant Research Project;

E-mail:kiokostar@yahoo.com increase in activities such as poaching, the exploitation of natural resources, and human-wildlife conflict leads to the constriction and degradation of wildlife habitats $[5,7,8]$.

The contraction of dispersal areas decreases the rate of migration of wildlife to and from protected areas, as many species are reluctant to use dispersal areas that have been altered by human settlement $[9,10]$. The loss of dispersal areas limits the ability of a protected area to support viable, genetically diverse populations, rendering populations prone to inbreeding depression and local extinction due to stochastic events and competitive exclusion [11]. In Tanzanian parks, consequences of insularization of parks have been local extinction of species, which have been higher in smaller parks than in larger parks. Therefore, dispersal areas around Amboseli National Park are important in limiting the effects of the park's small size [10].

The loss of dispersal areas around Amboseli is linked to recent changes in land tenure and land use in the Maasai group ranches [12-16]. Land tenure is an important consideration in environmental management and conservation, as it defines and regulates access to environmental resources [17]. The shift from communal land tenure to individual land tenure within the Amboseli ecosystem has contributed to environmental degradation and unsustainable use of natural resources within Amboseli National Park's dispersal areas affecting their ability to support viable wildlife populations [18]. The Land (Group Representatives) Act that governs group ranches was introduced in 1968 and was viewed as a compromise between individual ownership and the need for access to wider resources in the arid and semi-arid lands [17-19]. 
However, the group ranches have largely been ineffective in advancing Maasai livelihoods and have instead heightened numerous social and ecological issues. For one, mismanagement by group ranch officials and group ranch subdivision has contributed to an increase in agriculture and human population and the loss of land for wildlife and livestock [20]. Subdivision of the group ranches may have negative implications for wildlife conservation. With the privatization of land, the people are likely to focus on shortterm economic interests at the expense of wider, long-term interests [18]. In addition, expansion of agriculture poses one of the most serious no threats to wildlife dispersal areas in the group ranches around Amboseli. Clearing rangelands for agriculture destroys habitat resources, and fencing farms limits the space available for wildlife movement. For every $1 \%$ reduction in ranch area, about $1.2 \%$ loss of wildlife is due to habitat loss [21]. In addition to destroying wildlife habitats, intensive agriculture results in degradation of critical habitats. For example, the Kimana and Ilchalai swamps to the east of Amboseli National Park once provided wet season water and grazing for wildlife, but today much of their water has been diverted to irrigate farms [6].

Another significant consequence of inularization and extinction of species of Amboseli would be lost of tourism appeal, hence loss of tourism revenue. Amboseli is a popular destination for tourists, who are drawn by the large mammal diversity in the park [22, 23]. Each year, Amboseli attracts over 140,000 tourists and brings in over 150 million Ksh (US\$2 million), which provides the financial means for wildlife conservation in the region [24, 25]. However, the future of Amboseli as a conservation area and tourist destination is threatened by the increasing contraction, degradation and zoo - like conditions due to continuous loss of dispersal areas in surrounding Maasai group ranches due to human activities and structures.
A greater understanding of wildlife distributions in relation to human activities around Amboseli National Park will reveal the dispersal status of Olgulului - Ololorashi group ranch and implications for Amboseli National Park. Studies in other group ranches in the ecosystem suggest that spatial arrangement of human clusters of activities may be a more universal threat than the actual space available for wildlife $[7,20]$.

The specific objectives of the study were to:

i) Establish the area and spatial distribution of land available for wildlife and livestock through mapping the area occupied by human structures and activities in Olgulului-Ololorashi Group Ranch.

ii) Determine the average minimum distance that wildlife kept away from various human structures and activities, as an index of wildlife displacement by human activities.

iii) Identify the distribution of large mammal wildlife species in the group ranch, and in different habitats of the Group Ranch.

iv) Examine the consequences of the findings on conservation efforts in the dispersal areas and make appropriate recommendations for successful wildlife conservation in the area.

\section{STUDY AREA}

This study was carried out around Amboseli National Park in the Olgulului-Ololorashi Group Ranch in the Loitokitok District of Southern Kenya during the wet season (November 2008 and April 2009), though the area was experiencing a drought. Olgulului-Ololorashi Group Ranch (Fig. 1) borders Eselenkei Group Ranch to the north, Mbirikani Group Ranch to the northeast, Kimana Group

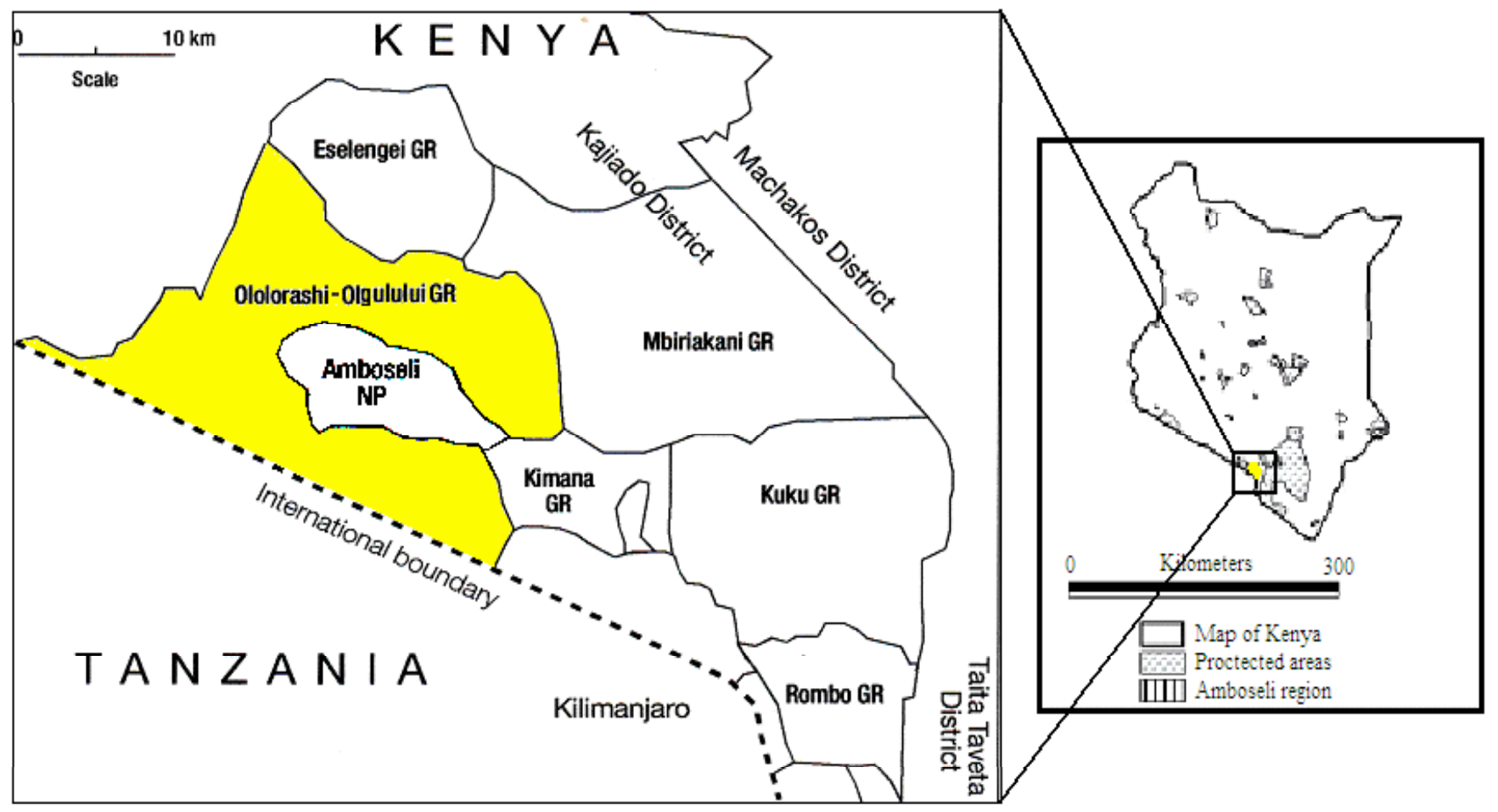

Fig. (1). Amboseli Ecosystem showing the location of Olgulului-Ololorashi Group Ranch in Kenya. 
Ranch to the southeast, and the Tanzanian international border to the south.

Olgulului-Ololorashi surrounds $90 \%$ of Amboseli National Park. Olgulului-Ololorashi group ranch covers $1232 \mathrm{~km}^{2}$. The remaining area in the district consists of individual holdings, mostly along the footslopes of Mt. Kilimanjaro to the south east of Amboseli National Park [26]. The group ranch was incorporated in 1975 as part of the government sponsored land settlement scheme of 1968 [19]. The group ranches have steadily increasing membership populations. In 2001, the group ranch had 3,418 members [19]. Pastoralism is the primary economic livelihood in the region and for most of the inhabitants of the group ranches.

Amboseli National Park is almost completely surrounded by Olgulului-Ololorashi Group Ranch, thus making it an important wildlife dispersal area for the park [19]. In 1947, the colonial government established Amboseli National Reserve from 3,260 $\mathrm{km}^{2}$ of Maasai land [4]. In 1974, after heated political discourse, today's $392 \mathrm{~km}^{2}$ Amboseli National Park was gazetted [4]. Amboseli is currently too small to support all of the wildlife that is currently in the $5,000 \mathrm{~km}^{2}$ dispersal area [4]. During the dry season, wildlife congregates in Amboseli, where there are permanent swamps and disperses into the surrounding group ranches during the wet season when water and forage is plentiful [3, 4].

Olgulului-Ololorashi Group Ranch is primarily a semiarid to arid pastoral land unsuitable for agriculture. Rainfall in the area follows a seasonal pattern of short rains, typically between October and December, and long rains between March and May. The study area around Amboseli National Park receives low rainfall of $500 \mathrm{~mm}$ or less [26]. The majority of lowland soils are dominated by saline sodic conditions and highly susceptible to erosion [27]. Due to the relatively recent volcanic activity, much of the Horizon A top soils are shallow and unproductive, more suitable for pastoralism and wildlife [28]. The plant communities of the Amboseli basin are dominated by bushland and open grassland. A typical composition of Acacia-Commiphora can be found throughout the region, along with a varying gradient of grassland to open woodland habitat. Species such as Acacia tortilis, Acacia xanthophloea, Azima tetracantha, and Suaeda monoica are represented within the lowlands [27]. Recent trends show reduction in the amount of woodland cover in most of the group ranches as bush encroachment takes place and both rainfed and irrigated agriculture expand [19]. Shift from nomadic pastoralism to sedentarisation by the Maasai, has led to severe rangeland degradation which has resulted in loss in range productivity and increased erosion [29].

\section{MATERIALS \& METHODS}

Assessment of the human infrastructure and activities in Ololorashi-Olgulului Group Ranch was done in the wet season in November 2008 and concluded in April 2009. Most of the mapping was done on foot, except for the mapping of roads, which was done in vehicles. For purposes of safety and area navigation, four research teams were accompanied by Kenya Wildlife Service rangers as well as local Maasai guides. Global positioning units (GPSmap 76CSx, 1999, Garmin Ltd) were used to determine the UTM coordinates of wildlife and human structures in the group ranch, including bomas, roads, institutions (public places such as churches, schools, hotels, administrative areas) and cattle watering areas and tanks. The shape and dimensions of each structure were recorded for the purposes of determination of the area covered.

The distance animals were sighted to the nearest different human infrastructure was considered an index of wildlife displacement of that human structure / activity. Even though mostly reliable, the weakness with this index was that it could have been biased with general animal density and distribution in the area; and it could vary depending on the time of the day; and animals could avoid the area depending on the activities and occupancy of those human structures. Nevertheless, it was considered a realistic and reliable index of wildlife displacement by human infrastructure. All spatial data was compiled in Excel 2002 (Microsoft Corporation, Troy, New York) and spatially analyzed using ArcViewGIS 3.3 (Environmental Systems Research Institute Inc., 1999).

\section{Bomas}

In this study, bomas were defined as individual structures or groups of structures erected for living purposes by the Maasai. Traditional bomas are generally surrounded by a fence of Acacia branches and consist of housing units that surround a central livestock pen. All bomas within the study area were mapped based on land surveys and on knowledge of local guides. The status of use of the bomas was assessed as occupied, unoccupied, abandoned, or new. Occupied bomas were defined as those with current residents, unoccupied bomas were in use seasonally but had no current residents, abandoned bomas were no longer in use, and new bomas were either recently completed or in the process of completion and were not yet inhabited. The shape of each boma was also recorded as a circle, oval, rectangle, or irregular, so that area could be calculated.

Within each boma, the total number of housing structures was recorded and the permanence of each of the structures in the boma was classified as permanent, semi-permanent, temporary, or incomplete, based on the dominant construction materials. Permanent units had foundations of concrete and metal or iron (tin) roofs, and the walls were constructed with wood or brick. Semi-permanent units had metal (tin) roofs but lacked concrete foundations, and the walls were made of either mud or of wood. Temporary units had grass roofs, mud walls, and no concrete foundations. Temporary structures that had been partially destroyed but were still standing were classified as temporary. Incomplete units were defined as structures in the process of being constructed within a boma. Units that were no longer standing were not counted or classified.

Global Positioning Systems (GPS) were used to determine the location of each boma by taking the GPS coordinates of the center point of the boma. The dimensions (in meters) of each boma were recorded based on subjective fitting of a polygon and the appropriate dimensions used to calculate the respective areas. Where the structure was irregular multiple GPS points were recorded around the perimeter of each boma and the points into ArcView for area calculation. 


\section{Other Structures and Agricultural Areas}

Other structures were defined as those constructions, excluding bomas and roads, and included schools, churches, hotels, water tanks, fences, and other structures, as well as agriculture. Agricultural infrastructure consists of smallscale or large-scale farming. Similar procedure for determining the location and area of the boma described above was used for the institutions and agricultural areas.

\section{Roads}

Roads were mapped by driving their length to establish their spatial location and area. For each road, GPS coordinates were recorded at every $1 \mathrm{~km}$, with increased frequency of recording when the road curved. At each point, the width of the road was also estimated. The length of each road was calculated from GIS spatial analysis. Based on the width and length, the area of each road was calculated. Roads were identified based on destination (regions connected) and were classified as main, major, or minor roads. A main road was wider than 8 meters, a major road between 2 and 8 meters wide, and a minor road less than 2 meters wide.

\section{Wildlife Large Mammal Distribution}

The primary purpose of wildlife large mammal sightings in this study was to determine the distribution in relation to the human structures and activities, and also the displacement effect of human structures and activities, rather than to determine wildlife distribution and density. Although wildlife data was collected throughout the mapping process, several days were dedicated exclusively to collecting data on wildlife. When possible, hills were used as vantage points where the research team scanned for wildlife using binoculars. Researchers walked to where wildlife had first been seen and took a GPS locative. Wildlife counts were done when wildlife was encountered. Most of the area was searched for wild large mammals. When wildlife was sighted, the species was identified, distance to the nearest human structure recorded, and the group size (number in the group as an index of abundance) determined.

For each wildlife group, the habitat it was located in was also classified as open or dense woodland, bushland, shrubland, or grassland. Open habitat referred to any habitat where maximum visual distance is at least 100 meters, while dense habitat referred to any habitat where maximum visual distance is 100 meters or less. Woodland consisted of woody vegetation taller than 10 meters, bushland between 6 and 10 meters, and shrubland less than 6 meters, while grassland consisted of only grass and herbaceous vegetation. .

The distance from the wildlife to location of each type of human structure and activity (bomas, infrastructures, livestock, or roads) within binoculars sighting distance (about $500 \mathrm{~km}$ to $1 \mathrm{~km}$ ) was determined by a range finder from the position where the wildlife was first sighted at. It was assumed that human activities at a distance greater than 500 meters did not affect wildlife location. If the wildlife was in proximity to more than one of a certain type of structure or activity, only the distance to the nearest structure or activity was recorded as an index of wildlife displacement. If there were livestock in proximity to the wildlife, the species of livestock was recorded as cattle, donkeys, or shoats (sheep and goats) and the group size of the livestock was recorded.

It was assumed that all the animals within viewing binoculars range were seen. Structures and activities far away outside visible range of binoculars were ignored. Depending on the cover, this may not have been correct, but a feel from the field provide some confidence that such an error was not so large to affect conclusions of this study. Further, it was assumed that all large wildlife seen were counted accurately, and the field work was done in such a way as to minimize both this location and count errors once animals were encountered. All large mammal species (primates and mammals larger than a dik dik, Madoqua kirkii Gunther) seen were recorded and the nearest (minimum) distance of wildlife from the point of initial location to the nearest different type of human infrastructure (whether agriculture, road, institution, homestead) was estimated using a Rangefinder (Bushnell® Laser Rangefinder, Yardage Pro ${ }^{\text {TM }} 400$, Bushnell Corporation, USA).

\section{Further Data Analysis}

GPS coordinates for bomas, agriculture, roads, institutions, and wildlife were input into Geographical Information Systems (ArcViewGIS 3.3 for Windows, Environmental Systems Research Institute Inc., 2005). Using the GIS areas of the irregular structures was determined and the spatial distribution of all the structure shown. Potential wildlife dispersal routes were identified based on the distribution of these clusters and wildlife distribution pattern. SPSS computer program (version 9.0 for Windows, SPSS Inc., 1999) was used for statistical analysis. The statistical tests were considered significant at alpha (type I error) of 5\% [30].

Standard mathematical formulae for circles, squares and circles were used to calculate areas of agriculture, bomas roads, and intuitions whose field geometrical shapes approximated the shapes of circles, rectangles and squares respectively. For irregular shape whose area could not be determined using these standard formulae, their area was determined from GIS program once the shapes were spatially drawn in the program. The total actual area and the area of wildlife displacement (with additional buffer added on their shapes in GIS program based on minimum average distance of wildlife large mammals from those structures) were computed for bomas, roads, and institutions in OlgululuiOlolorashi Group Ranch. The actual area and area with displacement were calculated for bomas, institutions, agriculture, and roads. Proportions of total areas and areas of displacement were calculated based on the area of the group ranch. A magnification factor was the number of times an area of an infrastructure inclusive of wildlife displacement was higher than the actual area occupied. Cluster areas and locations were delineated using GIS program by constructing the best polygon fit that lumped all closely located human structures and activities.

Average and standard errors were calculated for average minimum distance from wildlife large mammal distances to different types of bomas, different types of institutions, different types of roads, and to each livestock species. Averages and standard errors were also calculated for dimensions and areas of different types of bomas, number of 
different types of structures in each boma type, width of different types of roads, and group size of common wildlife species in different habitats.

Analysis of Variance (ANOVA) was conducted to determine differences in the average minimum distance of wildlife among boma types, road types, livestock species, and habitats (for distance to livestock only), and among all types of human activity (bomas, institutions, roads, and livestock) [30]. ANOVA tests were also used to determine differences in mean radius of boma types, average number of structures among bomas types, and width of road types. If results of the ANOVA reported significant differences in data (alpha < 0.05), a multiple variable Tukey (HSD) test was used to determine the significance of differences between all pairs of parameters. When comparing wildlife mean distances to occupied and unoccupied/abandoned bomas, Welch's approximate t-test was used to test for significant differences between the two distances [30].

The relationship between livestock group size and average minimum distance of wildlife to livestock was analyzed using a Pearson's correlation to establish the strength of the relationship between these variables. Nominal scale data on wildlife species and habitats was analyzed using enumerative statistical methods. Chi-squared goodness of fit test was used to identify significant differences between frequencies and abundances of common species across habitats. Chi-square cross tabulations were used to determine whether frequency and abundance of different species were independent of habitat type [30].

\section{RESULTS}

All human structures and activities were distributed throughout the group ranch (Fig. 2), and occupied a total actual area of $65.57 \mathrm{~km}^{2}(5.32 \%)$ of Olgulului - Ololorashi Group Ranch (Table 1). With wildlife displacement, the area taken increased about five times to $281.03 \mathrm{~km}^{2}(22.82 \%)$, leaving about $(77.18 \%)$ of the group ranch available to wildlife. Wildlife kept off from most human infrastructure and activities (Fig. 2). Wildlife maintained the greatest minimum distance from structures, followed by bomas, livestock, and finally roads (Table 1). The difference in distance wildlife maintained from these human structures/activities was significant $(\mathrm{F}=10.71, \mathrm{df}=3,614$, $\mathrm{p}<0.001)$. The difference was between institutions and bomas $(\mathrm{p}=0.02)$, institutions and livestock $(\mathrm{p}=0.002)$, and institutions and roads $(\mathrm{p}<0.001)$. Wildlife kept away further from occupied bomas followed by abandoned / unoccupied and lastly new ones (Table 2).

Multiple human activities were concentrated in 14 clusters in the group ranch (Fig. 4). These clusters occupied a total area of $199.25 \mathrm{~km}^{2}$ (10.82\% of the group ranch), leaving about $89.18 \%$ of land outside them. The largest clusters were the Kilimanjaro Rain-fed Agricultural Cluster $(2.62 \%)$, Lalakiri (1.85\%), and Olgulului (1.63\%). Other clusters are located mostly around Amboseli National Park were Mishenani Gate, Serena Lodge Area, and cultural bomas to the southern part of the Park. Clusters along the northern part of the park were small (Fig. 4), but in close proximity to each other. There were only $3.28 \mathrm{~km}$ between Mishenani Gate and Iltemwa, $2.84 \mathrm{~km}$ between Iltemwa and Naor-Enkare, and only $3.63 \mathrm{~km}$ between Naor-Enkare and Risa-Enchankla. This proximity left narrow wildlife dispersal and migration routes (Fig. 4) which would close up on the future if they expand.

There were 593 total bomas identified in Olgulului Ololorashi Group Ranch (Table 2). Some were occupied,

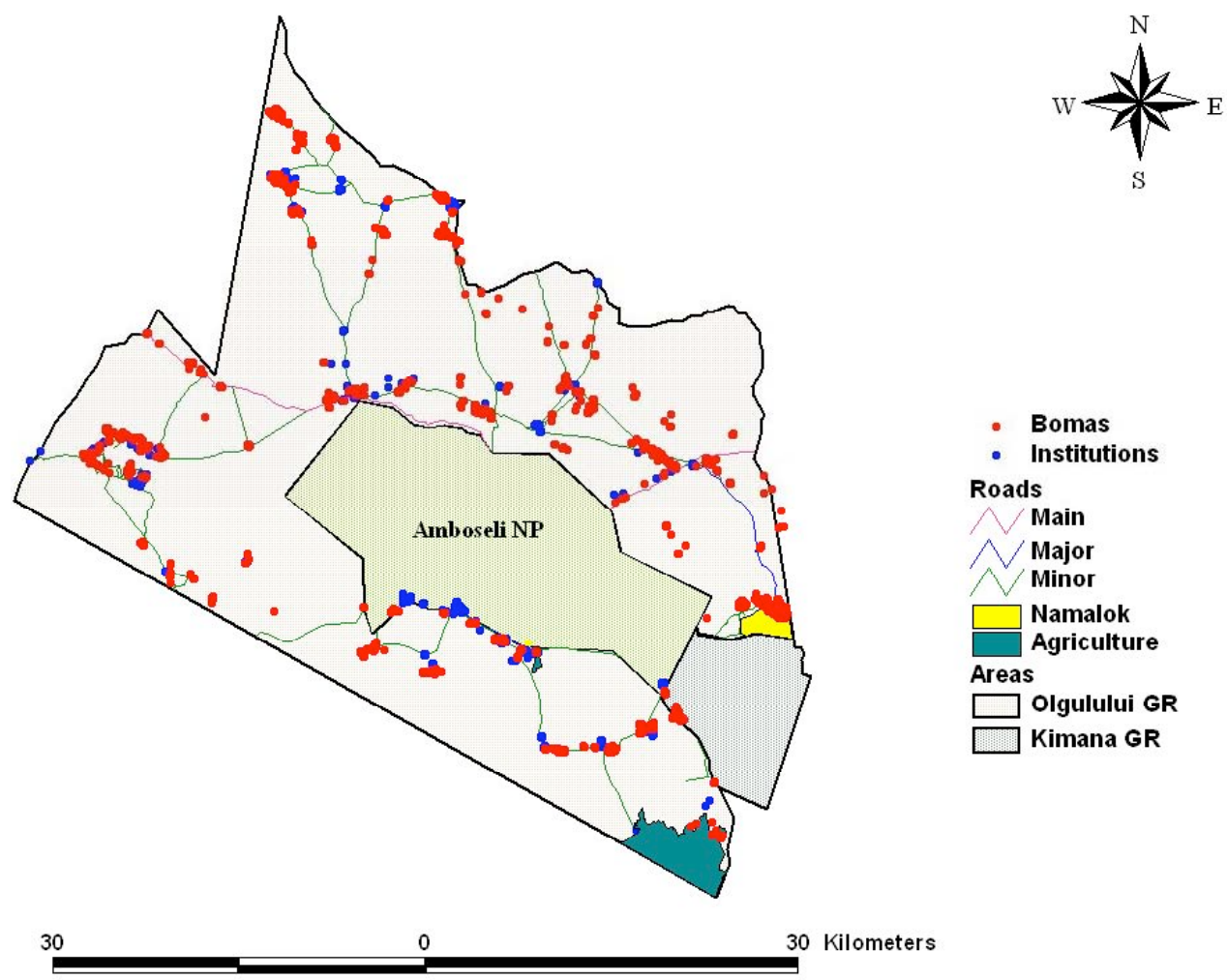

Fig. (2). Spatial location of all human activities/structures in Olgulului/Ololorashi Group Ranch. 
Table 1. Total Area and Percent Cover of all Human Structures with Wildlife Displacement in Olgulului-Ololorashi Group Ranch

\begin{tabular}{|c|c|c|c|c|c|}
\hline $\begin{array}{c}\text { Human } \\
\text { Structure/Activity }\end{array}$ & \multicolumn{2}{|c|}{$\begin{array}{c}\text { Areas without Displacement } \\
\left(\mathbf{k m}^{2}\right) \text { and \% }\end{array}$} & \multicolumn{2}{c|}{$\begin{array}{c}\text { Areas with Displacement } \\
\left(\mathbf{k m}^{2}\right) \text { and \% }\end{array}$} & $\begin{array}{c}\text { Times Higher than } \\
\text { Actual Area }\end{array}$ \\
\hline \hline Bomas & 1.095 & $0.089 \%$ & 123.168 & $10.00 \%$ & 112.48 \\
\hline Institutions & 35.39 & $2.87 \%$ & 66.84 & $5.43 \%$ & $2.13 \%$ \\
\hline Agriculture (rainfed) & 27.83 & $2.13 \%$ & 27.83 & $5.13 \%$ & 50.55 \\
\hline Roads & 1.25 & $0.102 \%$ & 63.19 & $22.82 \%$ & 4.29 \\
\hline Total & 65.57 & $5.32 \%$ & 281.03 & \\
\hline
\end{tabular}

Table 2. Characteristics of Bomas and the Relationship with Wildlife Displacement in Olgulului - Ololorashi Group Ranch

\begin{tabular}{|c|c|c|c|c|c|c|}
\hline Boma Status & $\begin{array}{c}\text { Mean } \\
\text { Radius of } \\
\text { Circular } \\
\text { bomas }(\mathbf{m}) \\
\text { (Mean } \pm \text { SE) }\end{array}$ & $\begin{array}{l}\text { Mean Length of } \\
\text { Rectangular } \\
\text { bomas }(\mathrm{m}) \\
(\text { Mean } \pm \text { SE) }\end{array}$ & $\begin{array}{l}\text { Mean Width of } \\
\text { Rectangular } \\
\text { bomas }(\mathbf{m}) \\
(\text { Mean } \pm \text { SE) }\end{array}$ & $\begin{array}{c}\text { Average boma Area } \\
\left(\mathbf{k m}^{2}\right) \\
(\text { Mean } \pm \text { SE })\end{array}$ & $\begin{array}{c}\text { Minimum } \\
\text { Distance to } \\
\text { Wildlife (m) } \\
\text { (Mean } \pm \text { SE) }\end{array}$ & $\begin{array}{l}\begin{array}{c}\text { Average Area with } \\
\text { wildlife Displacement }\end{array} \\
\left(\mathbf{k m}^{2}\right) \\
(\text { Mean } \pm \text { SE) }\end{array}$ \\
\hline Occupied & $23.88 \pm 0.62$ & $52.16 \pm 3.94$ & $35.02 \pm 2.27$ & $0.00217 \pm 0.00011$ & $261.03 \pm 23.97$ & $0.252 \pm 0.0043$ \\
\hline $\begin{array}{l}\text { Unoccupied (in } \\
\text { Ololorashi } \\
\text { section }^{1} \text { ) }\end{array}$ & $20.61 \pm 0.74$ & $25.25 \pm 6.76$ & $20.50 \pm 6.30$ & $0.00141 \pm 0.00010$ & $209.17 \pm 30.32$ & $0.167 \pm 0.0015$ \\
\hline $\begin{array}{l}\text { Abandoned (in } \\
\text { Ololorashi } \\
\text { section) }\end{array}$ & $18.44 \pm 1.09$ & - & - & $0.00118 \pm 0.00016$ & $100.63 \pm 24.62$ & $0.045 \pm 0.00085$ \\
\hline $\begin{array}{l}\text { Unoccupied/ } \\
\text { Abandoned }\end{array}$ & $21.55 \pm 0.60$ & - & - & $0.00163 \pm 0.00011$ & $192.12 \pm 18.24$ & $0.162 \pm 0.0044$ \\
\hline New & $17.81 \pm 1.32$ & $43.60 \pm 14.67$ & $31.60 \pm 4.85$ & $0.00123 \pm 0.00018$ & 120 & $0.054 \pm 0.0031$ \\
\hline All bomas & $23.29 \pm 0.96$ & $50.64 \pm 3.73$ & $34.02 \pm 2.12$ & $0.00196 \pm 0.000083$ & $213.88 \pm 14.90$ & $0.215 \pm 0.0038$ \\
\hline
\end{tabular}

abandoned, temporary or new. The majority of bomas were occupied $(60.54 \%)$, followed by unoccupied/abandoned $(34.41 \%)$. Further, the occupied bomas were larger (in terms of radius) followed by unoccupied / abandoned and lastly new ones (Table 2). The presence of new bomas in the group ranch $(4.05 \%)$ indicated that the number of bomas was either increasing or that old ones were being abandoned for new ones (Table $\mathbf{3}$ ).

Bomas had various housing structures of different types. Some of the structures were permanent, semi - permanent, temporary, or incomplete. The average number of structures per boma was $7.33 \pm 0.30$ ), and highest in occupied followed by unoccupied / abandoned and lastly in new bomas (Table 3). Further, the highest average numbers of structures were

Table 3. Average Number of Structures in Study Area and Average Number of Structures Per Boma Type

\begin{tabular}{|c|c|c|c|c|c|}
\hline Boma Status & $\begin{array}{c}\text { Average Structures Per } \\
\text { boma }(\text { Mean } \pm \text { SE) }\end{array}$ & $\begin{array}{c}\text { Permanent } \\
(\text { Mean } \pm \text { SE) }\end{array}$ & $\begin{array}{c}\text { Semi -Permanent } \\
(\text { Mean } \pm \text { SE) }\end{array}$ & $\begin{array}{c}\text { Incomplete } \\
(\text { Mean } \pm \text { SE) }\end{array}$ & $\begin{array}{c}\text { Temporary } \\
(\text { Mean } \pm \text { SE) }\end{array}$ \\
\hline \hline Occupied & $8.17 \pm 0.41$ & $0.25 \pm 0.05$ & $0.77 \pm 0.09$ & $0.56 \pm 0.05$ & $6.60 \pm 0.41$ \\
\hline $\begin{array}{c}\text { Unoccupied (in Ololorashi } \\
\text { section) }\end{array}$ & $7.14 \pm 0.61$ & $0.03 \pm 0.02$ & $0.04 \pm 0.02$ & $1.20 \pm 0.27$ & $5.87 \pm 0.51$ \\
\hline $\begin{array}{c}\text { Abandoned (in Ololorashi } \\
\text { section })\end{array}$ & $3.00 \pm 0.45$ & 0 & 0 & 0 & $3.00 \pm 0.45$ \\
\hline Unoccupied / Abandoned & $5.95 \pm 0.44$ & $0.01 \pm 0.01$ & $0.05 \pm 0.02$ & $0.52 \pm 0.13$ & $5.36 \pm 0.34$ \\
\hline New & $4.58 \pm 1.03$ & 0 & $0.08 \pm 0.05$ & $3.15 \pm 0.63$ & $1.35 \pm 0.69$ \\
\hline All bomas & $7.33 \pm 0.3$ & $0.17 \pm 0.03$ & $0.51 \pm 0.06$ & $0.67 \pm 0.06$ & $5.98 \pm 0.29$ \\
\hline
\end{tabular}


Table 4. Total Number of Structures and Total Number of Structures Per Boma Type in Olgulului - Ololorashi Group Ranch

\begin{tabular}{|c|c|c|c|c|c|}
\hline Boma Status & Total Number of Units & Permanent (\%) & Semi Permanent (\%) & Incomplete (\%) & Temporary (\%) \\
\hline \hline Occupied & $3098(72.15 \%)$ & $96(3.25 \%)$ & $288(9.75 \%)$ & $213(6.88 \%)$ & $2501(80.73 \%)$ \\
\hline $\begin{array}{c}\text { Unoccupied (in Ololorashi } \\
\text { section) }\end{array}$ & $564(31.58 \%)$ & $2(0.35 \%)$ & $3(0.53 \%)$ & $95(16.84 \%)$ & $464(82.27 \%)$ \\
\hline $\begin{array}{c}\text { Abandoned (in Ololorashi } \\
\text { section })\end{array}$ & $96(5.38 \%)$ & $0(0 \%)$ & $0(0 \%)$ & $9(0 \%)$ & $96(100.00 \%)$ \\
\hline Unoccupied/Abandoned & $1077(25.95 \%)$ & $2(0.19 \%)$ & $9(0.84 \%)$ & $95(8.82 \%)$ & $971(90.16 \%)$ \\
\hline New & $119(2.87 \%)$ & $0(0 \%)$ & $2(1.69 \%)$ & $82(68.91 \%)$ & $35(29.41 \%)$ \\
\hline All bomas & 4294 & $98(2.36 \%)$ & $299(7.20 \%)$ & $390(9.08 \%)$ & $3507(81.67 \%)$ \\
\hline
\end{tabular}

temporary followed by semi - permanent and lastly permanent structures (Table 3). The majority of structures were temporary $(81.67 \%)$, followed by semi-permanent $(7.20 \%)$, and permanent $(2.36 \%)$. The presence of new incomplete structures within bomas (9.08\%) was an indication that boma sizes were expanding (Table 4).

Institutions in the group ranch included government facilities, churches, schools, fences, lodges, airstrips, water points, markets, agriculture, and campsites. All other structures (other than bomas) occupied an actual area of $35.39 \mathrm{~km}^{2}(2.87 \%)$ and displaced wildlife from $66.84 \mathrm{~km}^{2}$ $(5.43 \%)$, about 1.89 times the actual area. Electric fences (including Namelok Agricultural Cluster) covered a larger space among the institutions, and further displaced wildlife from $8.74 \mathrm{~km}^{2}(0.71 \%$ of Olgulului - Ololorashi Group Ranch). Although agriculture covered more land than any other activity in Olgulului-Ololorashi Group Ranch $(2.13 \%)$, it was limited to the slopes of Mt. Kilimanjaro and within the Namelok Fence (Fig. 4). There was no wildlife sighted close to the rainfed agriculture on the slopes of Mt. Kilimanjaro, implying displacement beyond viewing distance.

There was a road network of $18.41 \mathrm{~km}$ length traversing though the entire group ranch (Fig. 3). Roads covered an actual area of $1.25 \mathrm{~km}^{2}(0.102 \%)$ in Olgulului-Ololorashi Group Ranch (Fig. 3), but with wildlife displacement distance, the area increased over 50 times to $63.19 \mathrm{~km}^{2}$

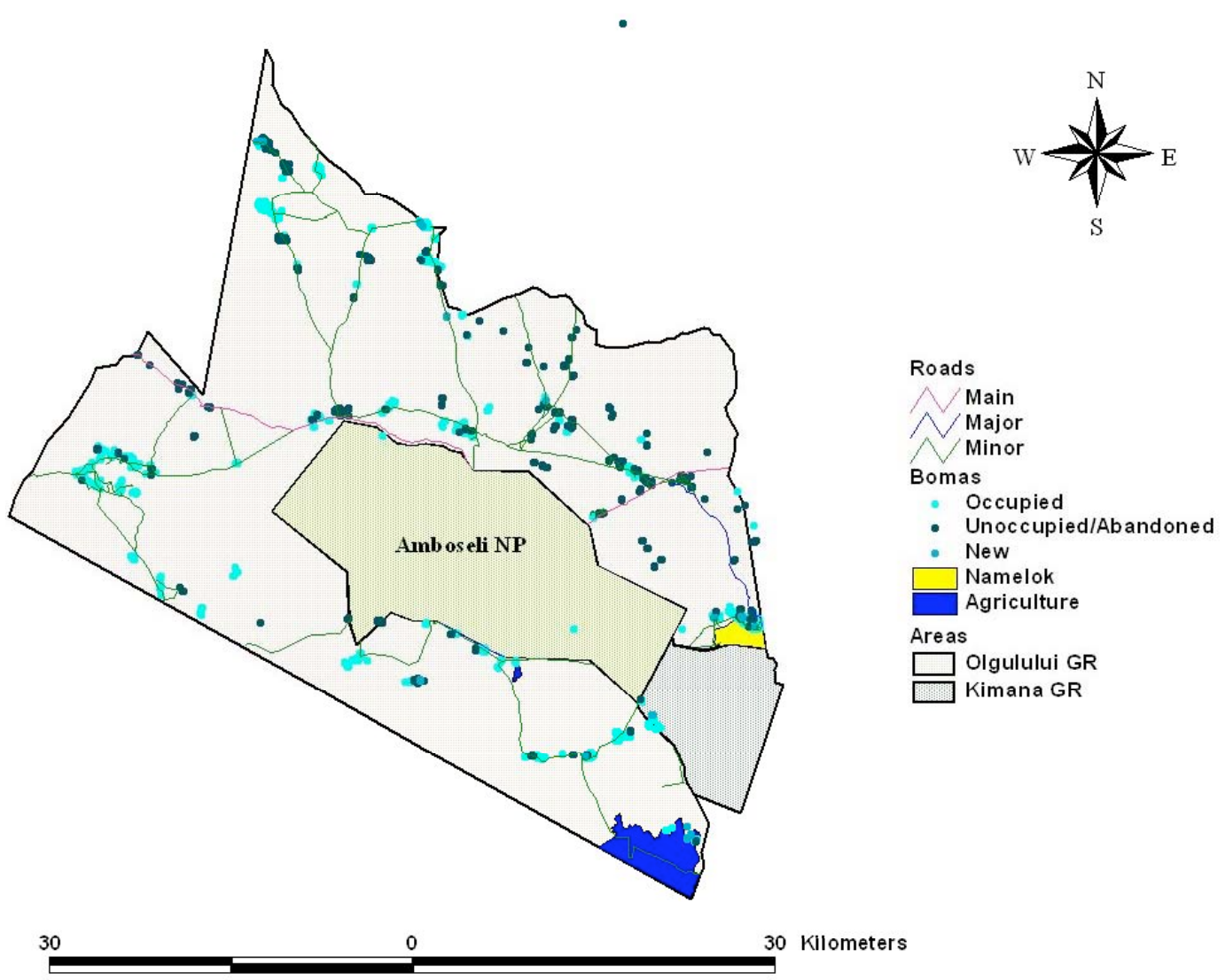

Fig. (3). Spatial distribution of different types of bomas in Olgulului/Ololorashi Group Ranch. 
(5.13\%) in Olgulului-Ololorashi Group Ranch. Minor roads made up the majority of the roads in the area, making up to $83.12 \%$ in network of roads. Main roads comprised only $11.95 \%$ of total road network, while major roads made up $5.39 \%$. The average minimum distance that wildlife kept away from roads was $163.02 \pm 8.68 \mathrm{~m}$ in OlgululuiOlolorashi. Overall, wildlife maintained an average minimum distance of $191.87 \pm 11.73 \mathrm{~m}$ from livestock. Wildlife large mammals kept off more from cattle followed by shoats and donkeys.

The average wildlife group size of wildlife large mammals across habitats was $6 \pm 1$. Larger group sizes were found in open habitats than in dense habitats. There were a total of 911 wildlife groups that comprised 5,405 individual large mammals sighted in all habitats (Fig. 4). Wildlife frequency was greatest in open shrubland, with $57.41 \%$ of the sightings, followed by grassland (19.43\%) and dense shrubland (10.21\%). Wildlife abundance was greatest in open shrubland $(55.86 \%)$, followed by grassland $(24.20 \%)$ and dense shrubland $(6.44 \%)$. Species abundance was dependent on habitat type $\left(\chi^{2}=365.27, \mathrm{df}=15, \mathrm{p}<0.001\right)$. Similarly, species frequency of occurrence was also dependent on habitat type $\left(\chi^{2}=55.94, \mathrm{df}=15 ; \mathrm{p}<0.001\right)$.

\section{DISCUSSION}

Although human infrastructures occupied a relatively small actual area in Olgulului - Ololorashi Group Ranch, wildlife was displaced from over a quarter of the group ranch. The large scale increase in the actual and wildlife displacement areas by human developments indicates that effects on wildlife are not simply due to the actual area occupied by the development. The developments are hubs of human activities [31]. The effects of the developments to wildlife are exemplified by human hostility and resource competition depending on their size and distribution $[4,32]$. Effects of human activities on wildlife space are most severe if a larger area of the dispersal area is covered and when activities (such as snaring for bushmeat, harassment, and persecution of wildlife) discourage wildlife from coming in close proximity with human dwellings [33-35]. These hostile actions against wildlife are magnified if human hub locations (such as agriculture areas, roads, bomas, social amenities) are distributed throughout the dispersal areas, hence negatively affecting wildlife in much larger area

In some Maasai group ranches within the the Amboseli ecosystem (such as Mbirikani and Kuku) the land still available to wildlife comprises over $75 \%$ of the group ranch [20]. But some, like Kimana Group Ranch, have about half of land still available to wildlife and have settlement clusters poorly oriented within wildlife movement corridors [8]. This is further complicated when there are several clusters oriented in the same way and growing towards each other as is the case of Olgulului - Ololorashi Group Ranch. The presence of new Maasai bomas among the human settlement clusters clearly indicates that the settlement clusters were expanding. The Maasai settlement pattern tend to be clustered along critical resources such as transport (along roads), near fertile areas for cultivation, and along rivers and swamps [36]. The effect of the bomas depends on the degradation level, how long they stay in an area and how long they take to recover. Displacement may occur when they are occupied, but when abandoned the rate of

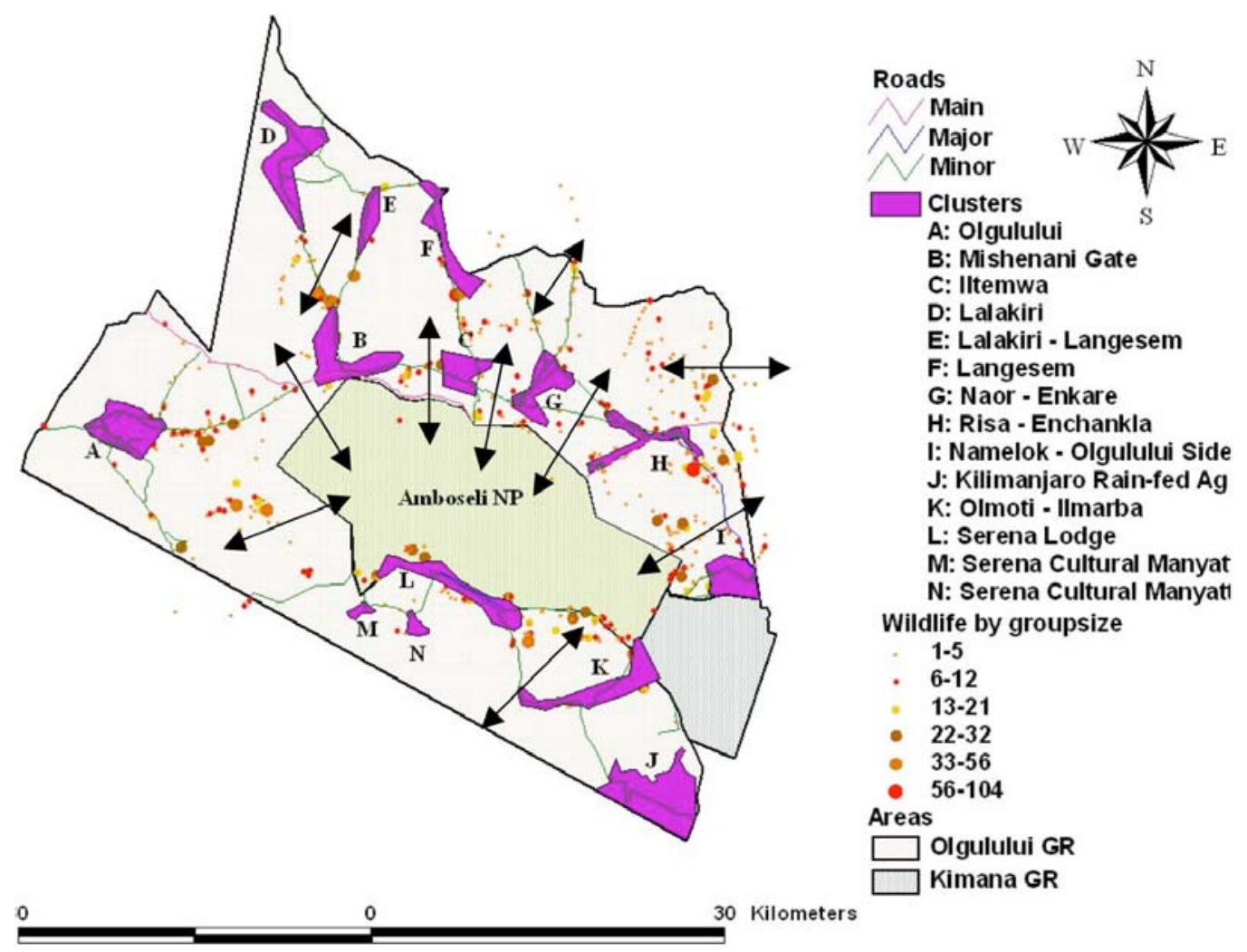

Fig. (4). The potential migration and dispersal routes used by wildlife among areas of multiple human structures/activities in Olgulului/Ololorashi Group Ranch. 
disintegration and breakdown produces a rich fertile spot for vegetation regeneration and succession that become a focal point for wildlife use [37]. But where there is permanent settlement especially as a result of group ranch subdivision, the resulting wildlife displacement may be permanent, hence making this the single most important threat to the viability of a protected area [38].

Wildlife displacement by occupied bomas was significantly greater than displacement by unoccupied/ abandoned bomas, which indicates that level of human activity influences the minimum distance that wildlife keeps from bomas, most likely because they are used year-round hence continous wildlife disturbance. Although all of the structures observed in abandoned bomas were temporary and will eventually decay, the building materials for these structures were usually harvested from the surrounding area, reducing the available wildlife forage. Establishment of bomas also involves vegetation clearing, extraction for fuelwood needs, charcoal burning, medicinal purposes, and construction materials [39, 40]. Furthermore, trampling by livestock leads to soil compaction and loss of vegetation cover [41], making such areas undesirable for wildlife. However, this is only permanent and most serious where such human activities are permanent, but with sufficient rainfall, vegetation is likely to recover in one season and make up for resource use and this temporary degradation.

No wildlife was seen close to the agricultural cluster. Agriculture displaces wildlife through increased humanwildlife conflict, as farmers spear, poison, or snare wildlife in retaliation for crop damage or for bushmeat [34]. In the area around Amboseli National Park, irrigation - based agriculture was confined to a small area within the Namelok fence, where, water resources are heavily extracted for water, and do not allow it to flow outside the fence for wildlife use [20] hence affecting wildlife use of range and distribution [3]. While, the rest of Olgulului-Ololorashi Group Ranch is unsuitable for agriculture due to limited rainfall and poor soils, it seems that rainfed agriculture on the slopes of Mt. Kilimanjaro is spreading down into the rangelands of Olgulului - Ololorashi Group Ranch [19] and is an immediate threat to the wildlife range. Further, even though electric fencing around agriculture is designed to eliminate human-wildlife conflict in agricultural areas, electric fences displace human-wildlife conflict to other areas rather than resolve them [20,42]. Fences also encourage settlement and growth of markets around the fences, as was observed in Namelok [20]. Fences can also lead to local species extinction by excluding wildlife from key watering points $[38,42]$ and inhibiting wildlife movement.

Although roads occupied less than two square kilometers, they had a large effect on wildlife displacement because of the large network and distributed throughout the group ranch. Tourists traveling to and from Amboseli National Park make extensive use of the two main roads to the park, but due to light human and vehicle traffic within the group ranches, other roads are not as used. However, large trucks use these other roads in search of infrastructure construction materials (murram, ballast, and rocks) and for transporting water to bomas. Most of the roads were poorly maintained and were prone to erosion and flooding, which has led to the creation of a large network of unnecessary parallel minor roads that degrade the rangelands. In Mikumi National Park in Tanzania, several wildlife species were frequently found $600 \mathrm{~m}$ from a major transnational highway [38]. Therefore, the width of the road may not necessarily be the best predictor of its use, but in combination other factors such as road kills, wildlife harassment, degree of fragmentation, frequency and intensity of use.

Livestock does not permanently displace wildlife, but compatibility with wildlife conservation and sharing of range resources is dependent on various factors [43]. In this study, wildlife maintained a smaller distance to livestock than to human structures. Livestock may only be compatible with wildlife use of range if resources are abundant, if foraging strategies and habitat use are not competitive and if livestock is not accompanied by bell noises and wildlife harassment from its herders $[4,36,44]$. Livestock can displace wildlife through competitive exclusion. Wildlife kept the greatest distance from cattle, compared to shoats and donkeys possibly because cattle compete with bulk grazers for forage [36]. Furthermore, cattle are in larger groups, are more frequently accompanied by humans, and often have loud bells $[13,45]$.

Maintaining habitat diversity is important because species have different requirements, and heterogeneous habitats provide a greater number of niches [46]. If habitats are lost or homogenized, local species extinction may occur because species are unable to adapt or are driven to extinction by competitive exclusion. Wildlife was most often found in open shrubland, which may be related to the fact that the study area mostly composed of open shrubland. Open shrubland provides a variety of niches for browsers and grazers, and provides thermal cover, and nesting cover [20]. The high percentage of wildlife sightings in the grassland can be attributed to the fact that the majority of wildlife species observed were grazers [47]. Also, large wildlife groupings occur in the grassland because many plains grazers form large herds. In addition, large number of sightings in open habitats, including grassland, open shrubland, and open bushland, may be attributed to higher visibility in these habitats. The dispersal areas must not just present open space for wildlife use, but also quality habitat [46]. Habitat influenced both species group size (abundance) and presence for most observed species of wildlife.

Species-habitat relations must be considered individually when evaluating the status and condition of potential dispersal areas, as species have different ecological needs $[46,48]$. Several species, including the lesser kudu (Tragelaphus inberbis Blyth) and gerenuk that are rarely found within Amboseli National Park occurred within the group ranch most likely due to the high habitat diversity within Olgulului. A special effort should be made to understand the habitat needs of endangered, keystone, and flagship species found in the group ranches, such as the cheetah, lions and elephants and analyze the species range beyond the confines of the relatively smaller sized Amboseli National Park. Wildlife dispersal into group ranch areas is critical in supporting the emerging community conservation areas $[49,50]$ and relieving Amboseli National Park the pressure of large animal biomass. Tourism can be encouraged in the private protected areas that allow unique tourism events (such as hiking, horse riding, night game 
drives, and cultural interactions with the Maasai) that are not allowed in Amboseli National Park [51].

\section{CONCLUSIONS AND WAY FORWARD}

The findings and implications of this study are important in understanding the danger of insularization of Amboseli National Park. Urgent initiatives are needed if the Maasai group ranches are to remain viable wildlife dispersal areas. The expansion of clusters of human settlement and activity around the park could potentially close the existing wildlife movement routes into and out of the park. These dispersal areas are important in providing feeding and breeding sites, limiting resource competition, and maintaining genetic health of populations $[10,52]$. Without these dispersal areas, the health of wildlife populations within Amboseli will likely diminish due to inbreeding and increased vulnerability to demographic and environmental stochasticity [11]. Species with specialized diets, large home ranges, and reliance on other species will be particularly susceptible to local extinction if the dispersal areas around Amboseli become blocked [53]. Within the Mara-Serengeti ecosystem in Kenya, considerable land cover change due to human activity has led to a $>50 \%$ decline in wildlife numbers in 20 years, while wildlife numbers have remained constant in the Tanzanian dispersal areas, where land cover change has been negligible [54]. A land use plan, co-developed by local communities and the ecosystem stakeholders, should restrict land uses that are incompatible with local ecology and culture $[13,14,20,33,55]$. The development of permanent structures and infrastructure should be confined to a few designated clusters. Agreements could be made between landowners and conservation stakeholders to designate certain areas as wildlife/pastoral zones, which would be binding upon successive owners [17]. The land owners should be empowered to participate in conservation through awareness, enactment of transparent benefit system and participation for them to view wildlife as viable land use option.

Economic incentives for conservation are critical in developing rural communities, where conservation cannot be justified for aesthetic reasons [56, 57]. Revenue sharing between the Kenya Wildlife Service (KWS) and group ranches has yielded mixed results due to mismanagement and inadequate payments, but a revival of this program may foster an improved relationship between the park and the group ranches [58]. Throughout the group ranches now, ecotourism investments have provided income and employment opportunities, which have led to improved infrastructure and more positive local attitudes towards wildlife [59]. However, this should be managed to reduce exploitation of the local communities and improve equitable distribution of tourism benefits with investors. Conservation organizations may lease land at market prices from landowners or group ranch members so that it may be set aside for wildlife [20]. Other than land leases, consolation schemes and other wildlife conservation cost - deflecting mechanisms to the local communities [60] currently being undertaken should be improved within the Amboseli Ecosystem. Community wildlife conservation areas have the potential to bring tourism revenue to local people, so long as they are properly designed, supported by communities and leaders, and economically viable [44, 49]. For example, the
Kimana Community Wildlife Sanctuary earns members of Kuku Group Ranch over Ksh 7 million annually [51]. A similar community conservation area has been proposed in Kuku Group Ranch [49, 51]. These conservation areas should be linked to each other and to Amboseli National Park so as to protect key wildlife dispersal areas and corridors. Finally, people living in the dispersal areas should be compensated not only for wildlife-related injury but also property damage, including predation of livestock and crop raiding, so that people do not resort to retaliatory killing of wildlife [33].

Complementary research should examine the actual use of the identified wildlife dispersal areas and potential routes. The role of rangeland degradation in displacement of wildlife in the ecosystem [61] should be studied and remedies suggested. Studies on habitat availability and suitability, and selection by key wildlife species need to be undertaken. Finally, trends in human population and development, and monitoring of human settlement cluster expansion around Amboseli should be consistently done so that appropriate recommendations can be made to limit the effects of development on wildlife dispersal areas. The ongoing process of establishing community owned conservations areas outside Amboseli National Park can benefit from studies like this so as to ensure that the sites chosen complement the long term goals of managing wildlife in the Amboseli ecosystem.

\section{ACKNOWLEDGEMENTS}

We would like to thank the School for Field Studies and the Center for Wildlife Management Studies for providing the equipment and resources for this study. This work was accomplished through the Fall 2008 team: Belton Copp, Nicolas Blake, Catie Couper, Spencer Fellows, Laura Fransisco, Emma Giboney, Jessica Heinz, Joshua Munnell, Manuel Padilla, Jennifer Redman, and Trea Schumacher; and the spring 2009 team: Kaitlyn Gaynor, Jason Baillio, Dylan Beach, Judy Buchanan, Keriann Cabral, Angela Darnell, Amber Goguen, Anne Guillen, Marian Howe, Kelsey Howe, Connor Jandreau, and David Kramer. This research would not have been possible without the support and cooperation of the Olgulului-Ololorashi Group Ranch members and officials, who welcomed us onto their land. Finally, we thank KWS staff and the numerous local guides for their assistance.

\section{REFERENCES}

[1] Newmark WD. The role and designing of wildlife corridors and examples from Tanzania. Ambio 1993; 22(1): 500-4.

[2] Wishitemi B, Okello MM. Application of the protected landscape model in southern Kenya. Parks 2003; 13(2): 12-21.

[3] Western D. Water availability and its influence on the structure and dynamics of a savannah large mammal community. E Afr Wild J 1975; $13: 265-85$.

[4] Western D. Amboseli National Park: enlisting landowners to conserve migratory wildlife. Ambio 1982; 11(5): 302-8.

[5] Newmark WD, Hough JL. Conserving wildlife in Africa: integrate conservation and development projects and beyond. BioScience 2000; 50 (7): 585-92.

[6] Okello MM, D'amour DE. Agricultural expansion within Kimana electric fences and implications for natural resource conservation around Amboseli National Park, Kenya. J Arid Environ 2008; 72: 2179-92. 
[7] Okello MM. In: Toshio M, Ed. Reconceptualization of wildlife conservation ACTS. Nairobi, Kenya: Educational Publishers 2009; pp. 9-17.

[8] Okello MM. Contraction of wildlife dispersal areas and displacement by human activities in Kimana Group Ranch near Amboseli National Park, Kenya. Open Conserv Biol J 2009; 3: 4451.

[9] Shafer CL. In: Shafer CL, Ed. Island theory and conservation practice. Washington DC: Smithsonian Press 1990; pp. 101-10.

[10] Newmark WD. Insularization of Tanzanian parks and the local extinction of large mammals. Conserv Biol 1996; 10(6): 1549-56.

[11] Mech SG, Hallett JG. Evaluating the effectiveness of corridors: a genetic approach. Conserv Biol 2001; 15(2): 467-74.

[12] Kimani K, Pickard J. Recent trends and implications of group ranch sub-division and fragmentation in Kajiado Districts, Kenya. Geogr J 1998; 164: 202-13.

[13] Reid RS, Ogutu J, Rainy M, et al. Mara Count.People Wildlife and Livestock in the Mara Ecosystem. Mara Count 2002 Report. Nairobi, Kenya: International Livestock Research Institute 2003.

[14] Reid RS, Gichohi H, Said MY, et al. In: Galvin KA, Reid RS, Behnke RH, Hobbs NT, Eds. Fragmentation of semi-arid and arid landscapes: Consequences for human and natural systems. Dordrecht: Springer 2003; pp. 195-224

[15] Ogutu JO, Peipho HP, Dublin HT, Bhola N, Reid RS. Dynamics of Mara-Serengeti ungulates in relation to land use changes. J Zool 2009: 23(3): 278-98

[16] Boone RB, Burnsilver SB, Thornton PK, Worden JS, Galvin KA. Quantifying declines in livestock due to land subdivision. Range Ecol Manage 2005; 58, 523-32.

[17] Seno SK, Shaw WW. Land tenure policies, Maasai traditions, and wildlife conservation in Kenya. Soc Nat Res 2002; 15: 79-88.

[18] Ogolla BD, Mugabe J. In: Juma C, Ojwang, JB, Eds. In land we trust: environment, private property, and constitutional change ACTS environmental policy series 7. Nairobi, Kenya: Initiative Publishers 1996; pp. 23-34.

[19] Campbell DJ, Lusch DP, Smucker T, Wangui E. Root Causes of Land Use Change in the Loitokitok Area, Kajiado District, Kenya. The Land Use Change, Impacts and Dynamics Project Working Paper 19: Nairobi, Kenya: International Livestock Research Institute 2003.

[20] Okello MM, Grasty K. In: John D. Harris S, Brown PL, Eds. Wildlife protection, destruction and extinction. New York: Nova Science Publishers. Inc 2009; pp. 49-96.

[21] Norton - Griffiths M. Why Kenyan conservation is failing. Swara 1996; (40 ${ }^{\text {th }}$ anniversary edition): 6-8.

[22] Okello MM, D'amour, DE, Manka SG. Tourism attractions and satisfaction of Amboseli National Park, Kenya. Tour Anal 2008; 13: 373-86.

[23] Okello MM, Manka SG, D'amour DE. . The relative importance of large mammal species for tourism in Amboseli National Park, Kenya. Tour Manage 2008; 29: 751-60.

[24] Okello MM, Wishitemi BE, Mwinzi AM. Relative importance of conservation areas in Kenya based on diverse tourist attractions. J Tour Stud 2001; 12(1): 39-49.

[25] Okello MM, Wishitemi BEL, Lagat B. Tourism potential and achievement of protected areas in Kenya: criteria and prioritization. Tour Anal 2005; 10: 151-64.

[26] Ntiati P. Group Ranches Subdivision Study in Loitokitok Division of Kajiado District, Kenya. The Land Use Change Impacts and Dynamics Project Working Paper 7. Nairobi, Kenya: International Livestock Research Institute 2002.

[27] Githaga JM, Reid R, Muchiru AN, Van Dijk S. Survey of water quality changes with land use type in the Loitokitok Area, Kajiado District, Kenya. The Land Use Change, Impacts and Dynamics Project Working Paper 35. Nairobi, Kenya: International Livestock Research Institute 2003.

[28] Katampoi K, Genga G, Mwangi M, et al. Kajiado District Atlas. Kajiado, Kenya: ASAL Program 1990.

[29] McCabe TJ. Disequilibrial ecosystems and livelihood diversification among the Maasai of northern Tanzania: implications for conservation policy in eastern Africa. Nomad People 2003; 7(1): 74-91.

[30] Zar JH. Biostatistical analysis. $4^{\text {th }}$ ed. New Jersey: Prentice Hall Inc. 1999.

[31] Campbell DJ, Gichohi H, Mwangi A, Chege L. Land use conflict in Kajiado District, Kenya. Land use policy 2000; 17: 337-48.
[32] Okello MM. Land use changes and human-wildlife conflict in the Amboseli Area, Kenya. Hum Dimens Wild 2005; 10: 19-28.

[33] Okello MM, Kiringe JW. Threats to biodiversity and their implications in protected and adjacent dispersal areas of Kenya. J Sustain Tour 2004; 12(1): 55-69.

[34] Kiringe JW, Okello MM, Ekajul SW. Managers' perceptions of threats to the protected areas of Kenya: prioritization for effective management. Oryx 2007; 41 (3): 314-21.

[35] Wato YA, Wahungu GM, Okello MM. Correlates of wildlife snaring patterns in Tsavo West National Park. Kenya Biol Conserv 2006; 132(4): 500-9.

[36] Lamprey RH, Reid RS. Expansion of human settlement in Kenya's Maasai Mara: what future for pastoralism and wildlife? J Biogeogr 2004; 31: 997-1032.

[37] Muchiru A, Western D, Reid RS. The role of abandoned settlements in restructuring plant and wildlife communities, Amboseli, Kenya. Durban, South Africa: International Rangeland Congress 2003.

[38] Newmark WD. Isolation of African protected areas. Front Ecol Evol 2008; 6(6): 321-8.

[39] Sindiga I. Wildlife-based tourism in Kenya: land use conflicts and government compensation policies over protected areas. J Tour Stud 1995; 6(2): 45-55.

[40] Mcharia PN, Ekaya WN. The impact of rangeland condition and trend to the grazing resources of a semi-arid environment in Kenya. J Hum Ecol 2005; 17(2): 143-7.

[41] Oberson E. Impacts of livestock grazing on soils and recommendations for management. California: Native Plant Society 1996.

[42] Worden J, Reid R, Gichohi H. Land-use impacts on large wildlife and livestock in the swamps of the greater Amboseli ecosystem. Kajiado District, Kenya. The Land Use Change, Impacts and Dynamics Project Working Paper 27: Nairobi, Kenya: International Livestock Research Institute 2003.

[43] Fratkin E. Pastoralism: governance and development issues. Annu Rev Anthropol 1997; 26: 235-61.

[44] Okello MM, Seno SK, Wishitemi B. Maasai community wildlife sanctuaries in Tsavo - Amboseli , Kenya. Parks 2003; 13(1): 6275 .

[45] Campbell DJ, Gichohi H, Mwangi A, Smucker T. Globalization and local heterogeneity: an overview of diversity in land use and development issues in Loitokitok Division Kajiado District, Kenya. The Land Use Change, Impacts and Dynamics Project Working Paper 21: Nairobi, Kenya: International Livestock Research Institute 2003.

[46] Peek JM. A Review of Wildlife Management. New York: PrenticeHall 1986

[47] Estes RD. The behavior guide to african mammals: including hoofed mammals, carnivores, primates. California: University of California Press 1991.

[48] Mwangi EM, Western D. Habitat selection by large herbivores in Lake Nakuru National Park, Kenya. Biodivers Conserv 1998; 7: 18.

[49] Okello MM. An assessment of the large mammal component of the proposed wildlife sanctuary site in Maasai Kuku Group Ranch near Amboseli, Kenya. S Afr J Wildl Res 2005; 35(1): 63-76.

[50] Carter E, Adams WM, Hutton J. Private protected areas: management regimes, tenure arrangements and protected area categorization in East Africa. Oryx 2008; 42 (2): 177-86

[51] Okello MM. A survey of tourist expectations and economic potential for a proposed wildlife sanctuary in a Maasai group ranch near Amboseli, Kenya. J Sustain Tour 2005; 13(6): 566-89.

[52] Burkey TV. Faunal collapse in East African game reserves revisited. Biol Conserv 1994; 71: 107-10.

[53] Primack RB. Essentials of conservation biology. $2^{\text {nd }}$ ed. Sunderland, Massachussetts: Sinauer Associates Inc. 1998.

[54] Homewood KM. Policy, environment and development in African rangelands. Environ Sci Policy 2004; 7: 125-43.

[55] Rutten MME. Selling wealth to buy poverty; the process of the individualization of landownersh among the Maasai pastoralists of Kajiado District, Kenya, 1890 - 1990. Saarbrucken, Germany: Verlag Breitenbach 1992.

[56] Akama JS. The evolution of wildlife conservation policies in Kenya. J Third World Stud 1998; 15(2): 103-17.

[57] Hackel JD. Community conservation and the future of Africa's wildlife. Conserv Biol 1999; 13(4): 726-54. 
[58] Alpert P. Integrated conservation and development projects. Bioscience 1996; 46(11): 845-55.

[59] Ogutu ZA. The impact of ecotourism on livelihood and natural resource management in Eselenkei, Amboseli ecosystem, Kenya. Land Degrad Dev 2002; 13: 251-56.
[60] Ferraro PJ, Kiss A. Direct payments to conserve biodiversity. Science 2000; 298: 1718-19.

[61] Western D. A half a century of habitat change in Amboseli National Park. Kenya. African J Ecol 2006; 45: 302-10.

Received: March 04, 2010

Revised: April 01, 2010

Accepted: April 06, 2010

(C) Okello and Kioko; Licensee Bentham Open.

This is an open access article licensed under the terms of the Creative Commons Attribution Non-Commercial License (http://creativecommons.org/licenses/by-nc/3.0/) which permits unrestricted, non-commercial use, distribution and reproduction in any medium, provided the work is properly cited. 